\title{
Author Correction: c-Kit-positive ILC2s exhibit an ILC3-like signature that may contribute to IL-17-mediated pathologies
}

Jochem H. Bernink, Yoichiro Ohne, Marcel B. M. Teunissen (D, Jingya Wang, Jincheng Wu, Lisette Krabbendam, Christine Guntermann (D), Richard Volckmann, Jan Koster (D), Sophie van Tol, Ivan Ramirez (D), Yashaswi Shrestha (D), Menno A. de Rie, Hergen Spits D, Xavier Romero Ros and Alison A. Humbles (D)

Correction to: Nature Immunology https://doi.org/10.1038/s41590-019-0423-0, published online 1 July 2019.

In the version of this article initially published, the cell conversion was stated incorrectly ('ILC2s to ILC1-like cells') in the first sentence of the second paragraph in the second Results subsection; the correct description is 'ILC1s to ILC2-like cells'. Also, the far left plot in Fig. 1d was missing the vertical axis label; this should be 'IL-13-APC'. Finally, in the legend to Fig. 3a,b, the human ILCs were identified incorrectly $\left(\mathrm{CD} 45^{+} \mathrm{CD} 56^{-} \mathrm{CD} 127^{-}\right)$; the correct phenotype is $\mathrm{CD} 45^{+} \mathrm{CD} 56^{-} \mathrm{CD} 127^{+}$. The errors have been corrected in the $\mathrm{HTML}$ and PDF versions of the article.

Published online: 13 November 2019

https://doi.org/10.1038/s41590-019-0554-3

(c) The Author(s), under exclusive licence to Springer Nature America, Inc. 2019 